\title{
MEMBANGUN TATA RUANG TERBUKA HIJAU MENUJU LINGKUNGAN SEHAT DAN ASRI : SEBUAH ANALISA PERSPEKTIF HUKUM PENATAAN RUANG
}

\author{
Dian Ferricha, Dosen Fakultas Hukum Universitas Islam Balitar, Blitar, E-mail: \\ dianferricha2@gmail.com \\ Zulham Hakim, Dosen Fakultas Hukum Universitas Islam Balitar, Blitar, E-mail: \\ zulham_h@gmail.com
}

\begin{abstract}
That the development and growth of the city / urban is so significant accompanied by the rapid transfer of land functions, has caused environmental damage that can reduce the carrying capacity of land in sustaining the lives of people in urban areas, so it is necessary to make efforts to maintain and improve the quality of the environment through the provision of open space adequate green.
\end{abstract}

Keyword : law, land, environmental

\section{PENDAHULUAN}

\section{Latar Belakang}

Dalam sistem kosmos alam raya yang kita ketahui bersama terdiri dari padat/ darat, air, udara. Ketiga unsur tersebut merupakan hukum alam yang tidak dapat dipisahkan. Kita hidup pada salah satu bagian kecil dari sistem kosmos tersebut, yaitu bumi yang kita tempati.

Indonesia adalah bagian kecil dari bagian kecil dari belahan bumi dimaksud. Oleh karena menjadi bagian tersebut maka Negara Kesatuan Republik Indonesia (NKRI) juga mempunyai komponen kesatuan wadah yang meliputi ruang darat, ruang laut, dan ruang udara, termasuk juga ruang di dalam bumi. dan sumber daya yang ada. Hal tersebut merupakan karunia Tuhan Yang Maha Esa kepada bangsa Indonesia yang perlu disyukuri, dilindungi, dan dikelola secara berkelanjutan untuk sebesar-besar kemakmuran rakyat sesuai dengan amanat Undang-Undang1.

Ruang wilayah negara Indonesia dengan letak dan kedudukan yang strategis sebagai negara kepulauan merupakan sumber daya alam yang perlu dikelola secara terkoordinasi dan terpadu dengan sumber daya manusia yang handal dalam pola pembangunan yang berkelanjutan dan berwawasan lingkungan berlandaskan wawasan nusantara dan ketahanan nasional. ${ }^{2}$

Secara geografis, letak Negara Kesatuan Republik Indonesia yang berada di antara dua benua dan dua samudera sangat strategis, baik bagi kepentingan nasional maupun internasional. Secara ekosistem, kondisi alamiah Indonesia sangat khas karena posisinya yang berada di dekat khatulistiwa dengan cuaca,

${ }_{1}$ Lihat Pasal 33 ayat (3) Undang-undang Dasar 1945

2 Lihat konsideran dalam Peraturan Pemerintah Nomor 47 tahun 1997 tentang Rencana Tata Ruang Wilayah Nasional 
musim, dan iklim tropis, yang merupakan aset atau sumber daya yang sangat besar bagi bangsa Indonesia. Di samping keberadaan yang bernilai sangat strategis tersebut, Indonesia berada pula pada kawasan rawan bencana, yang secara alamiah dapat mengancam keselamatan bangsa. Dengan keberadaan tersebut, penyelenggaraan penataan ruang wilayah nasional harus dilakukan secara komprehensif, holistik, terkoordinasi, terpadu. ${ }^{3}$

Ruang wilayah tersebut diatas dapat dispesifikkan pada persoalan tanah/ darat sebagai tempat manusia berpijak dan tempat tinggal Penataan tata ruang dalam realitanya masih banyak ketimpangan dan menimbulkan masalah, utamanya di daerah perkotaan. Suatu misal dalam konsep perencanaan dan penyusunan rencana tata ruang di kota Palu yang tidak pernah memberikan kesempatan bagi masyarakat untuk terlibat aktif dalam proses penataan tersebut, karena kepentingan Pemerintah Kota Palu yang tidak membuka akses kepada publik untuk mengetahui dan terlibat didalamnya ${ }^{4}$. Ditambah lagi, masalah tumpang tindihnya antara kawasan pemukiman dan perdagangan di kota-kota besar yang cenderung mengabaikan tata estetika kota.

Bahwa perkembangan dan pertumbuhan kota/perkotaan yang demikian signifikan disertai dengan alih fungsi lahan yang pesat, telah menimbulkan kerusakan lingkungan yang dapat menurunkan daya dukung lahan dalam menopang kehidupan masyarakat di kawasan perkotaan, sehingga perlu dilakukan upaya untuk menjaga dan meningkatkan kualitas lingkungan melalui penyediaan ruang terbuka hijau yang memadai.

Berdasarkan dari uraian diatas, penulis ingin mengkaji secara lebih mendalam mengenai persoalan tersebut dengan pertimbangan bahwa hal ini sangat bermanfaat dalam mewujudkan pembangunan perkotaan yang berwawasan sosial, ekonomi serta memerlukan manajemen pertanahan yang handal. Hal ini sejalan dengan pembangunan perkotaan yang cenderung semakin luas sebagai konsekuensi dari meningkatnya kegiatan ekonomi dan pertumbuhan penduduk serta sebagai penggerak pembangunan di wilayah sekitarnya. Dengan demikian arah manajemen pertanahan harus selaras dengan pembangunan perkotaan.

Maka penulis mengkajinya dengan judul "MEMBANGUN TATA RUANG TERBUKA HIJAU MENUJU LINGKUNGAN SEHAT DAN ASRI : SEBUAH ANALISA PERSPEKTIF HUKUM PENATAAN RUANG" .

\section{Rumusan Masalah}

1. Bagaimanakah konsep tata ruang terbuka hijau perkotaan perspektif hukum penataan ruang ?;

\footnotetext{
${ }^{3}$ Konsideran dalam penjelasan atas undang-undang republik indonesia nomor 26 tahun 2007 tentang penataan ruang.

${ }^{4}$ Lihat dalam Siaran Pers: Jumat, 17 Desember 2004 (diambil dari situs www.walhi.or.id)
} 
2. Apa langkah yang harus dilakukan guna mewujudkan tata ruang terbuka hijau menuju lingkungan sehat dan asri menurut hukum penataan ruang ?

\section{TINJAUAN PUSTAKA}

\section{Pengertian Ruang Terbuka}

Ruang terbuka ialah ruang - ruang dalam kota atau wilayah yanglebih luas baik dalam bentuk area/ kawasan mapaun dalam bentuk area memanjang jalur dimana dalam penggunaannya lebih bersifat terbuka yang pada dasarnya tanpa bangunan. ${ }^{5}$

\section{Pengertian Ruang Terbuka Kawasan Perkotaan}

Ruang Terbuka Kawasan Perkotaan ialah bagian dari ruang terbuka suatu kawasan perkotaan yang didisi oleh tumbuhan dan tanaman guna mendukung manfaat ekologi, social, budaya, ekonomi dan estetika. ${ }^{6}$

\section{Kawasan Perkotaan}

Kawasan Perkotaan adalah kawasan yang mempunyai kegiatan utama bukan pertanian dengan susunan fungsi kawasan sebagai tempat permukiman perkotaan, pemusatan dan distribusi pelayanan jasa pemerintahan, pelayanan social dan kegiatan ekonomi.7

\section{PEMBAHASAN}

\section{KONSEP TATA RUANG TERBUKA HIJAU PERKOTAAN PERSPEKTIF HUKUM PENATAAN RUANG}

Ruang yang meliputi ruang darat, ruang laut, dan ruang udara, termasuk ruang di dalam bumi, sebagai tempat manusia dan makhluk lain hidup, melakukan kegiatan, dan memelihara kelangsungan hidupnya, pada dasarnya ketersediaannya tidak tak terbatas. Berkaitan dengan hal tersebut guna mewujudkan ruang wilayah nasional yang aman, nyaman, produktif, dan berkelanjutan berlandaskan wawasan nusantara dan ketahanan nasional, Undang- undang ini mengamanatkan perlunya dilakukan penataan ruang yang dapat mengharmoniskan lingkungan alam dan lingkungan buatan, yang mampu mewujudkan keterpaduan penggunaan sumber daya alam dan sumber daya buatan, serta yang dapat memberikan pelindungan terhadap fungsi ruang dan pencegahan dampak negatif terhadap lingkungan hidup akibat pemanfaatan ruang. Kaidah penataan ruang ini harus dapat diterapkan dan diwujudkan dalam

\footnotetext{
${ }^{5}$ Lihat Pasal 1 ayat 1 Peraturan Menteri Dalam Negeri Nomor 1 tahun 2007 Tentang Penataan ruang Terbuka hijau Kawasan Perkotaan.

${ }^{6}$ Lihat Pasal 1 ayat 2 Peraturan Menteri Dalam Negeri Nomor 1 tahun 2007 Tentang Penataan ruang Terbuka hijau Kawasan Perkotaan.

7 Lihat Pasal 1 ayat 3 Peraturan Menteri Dalam Negeri Nomor 1 tahun 2007 Tentang Penataan ruang Terbuka hijau Kawasan Perkotaan.
} 
setiap proses perencanaan tata ruang wilayah. ${ }^{8}$

Ruang sebagai sumber daya pada dasarnya tidak mengenal batas wilayah. Namun, untuk mewujudkan ruang wilayah nasional yang aman, nyaman, produktif, dan berkelanjutan berlandaskan wawasan nusantara dan ketahanan nasional, serta sejalan dengan kebijakan otonomi daerah yang nyata, luas, dan bertanggung jawab, penataan ruang menuntut kejelasan pendekatan dalam proses perencanaannya demi menjaga keselarasan, keserasian, keseimbangan, dan keterpaduan antardaerah, antara pusat dan daerah, antarsektor, dan antarpemangku kepentingan. Dalam pembahasan ini, penataan ruang didasarkan pada pendekatan sistem, fungsi utama kawasan, wilayah administratif, kegiatan kawasan, dan nilai strategis kawasan. Berkaitan dengan kebijakan otonomi daerah tersebut, wewenang penyelenggaraan penataan ruang oleh Pemerintah dan pemerintah daerah, yang mencakup kegiatan pengaturan, pembinaan, pelaksanaan, dan pengawasan penataan ruang, didasarkan pada pendekatan wilayah dengan batasan wilayah administratif. Dengan pendekatan wilayah administratif tersebut, penataan ruang seluruh wilayah negara kesatuan republik Indonesia terdiri atas wilayah nasional, wilayah provinsi.

Perencanaan tata ruang dilakukan untuk menghasilkan rencana umum tata ruang dan rencana rinci tata ruang. Rencana umum tata ruang disusun berdasarkan pendekatan wilayah administratif dengan muatan substansi mencakup rencana struktur ruang dan rencana pola ruang. Rencana rinci tata ruang disusun berdasarkan pendekatan nilai strategis kawasan dan/atau kegiatan kawasan dengan muatan substansi yang dapat mencakup hingga penetapan blok dan subblok peruntukan.

Penyusunan rencana rinci tersebut dimaksudkan sebagai operasionalisasi rencana umum tata ruang dan sebagai dasar penetapan peraturan zonasi. Peraturan zonasi merupakan ketentuan yang mengatur tentang persyaratan pemanfaatan ruang dan ketentuan pengendaliannya dan disusun untuk setiap blok/zona peruntukan yang penetapan zonanya dalam rencana rinci tata ruang. Rencana rinci tata ruang wilayah kabupaten/kota dan peraturan zonasi yang melengkapi rencana rinci tersebut menjadi salah satu dasar dalam pengendalian pemanfaatan ruang sehingga pemanfaatan ruang dapat dilakukan sesuai dengan rencana umum tata ruang dan rencana rinci tata ruang.

Penataan ruang yang didasarkan pada karakteristik, daya dukung dan daya tampung lingkungan, serta didukung oleh teknologi yang sesuai akan meningkatkan keserasian, keselarasan, dan keseimbangan subsistem. Hal itu berarti akan dapat meningkatkan kualitas ruang yang ada. Karena pengelolaan subsistem yang satu berpengaruh pada subsistem yang lain dan pada akhirnya dapat mempengaruhi sistem wilayah ruang nasional secara keseluruhan,

${ }^{8}$ Lihat dalam penjelasan atas undang-undang republik indonesia nomor 26 tahun 2007 tentang penataan ruang. 
pengaturan penataan ruang menuntut dikembangkannya suatu sistem keterpaduan sebagai ciri utama. Hal itu berarti perlu adanya suatu kebijakan nasional tentang penataan ruang yang dapat memadukan berbagai kebijakan pemanfaatan ruang. Seiring dengan maksud tersebut, pelaksanaan pembangunan yang dilaksanakan, baik oleh Pemerintah, pemerintah daerah, maupun masyarakat, baik pada tingkat pusat maupun pada tingkat daerah, harus dilakukan sesuai dengan rencana tata ruang yang telah ditetapkan. Dengan demikian, pemanfaatan ruang oleh siapa pun tidak boleh bertentangan dengan rencana tata ruang.

Sehingga, makna penataan tata ruang merupakan suatu sistem perencanaan tata ruang, pemanfaatan ruang, dan pengendalian pemanfaatan ruang merupakan satu kesatuan yang tidak terpisahkan antara yang satu dan yang lain dan harus dilakukan sesuai dengan kaidah penataan ruang sehingga diharapkan dapat mewujudkan pemanfaatan ruang yang berhasil guna dan berdaya guna serta mampu mendukung pengelolaan lingkungan hidup yang berkelanjutan

Sebelum membahas lebih jauh mengenai konsep tata ruang terbuka hijau perkotaan selayaknyalah harus memahami suata definisi dan deskripsi yang dapat membantu untuk menangkap makna subtantif dari yang dimaksud. Ruang terbuka merupakan ruang-ruang dalam kota atau wilayah yang lebih luas baik dalam bentuk area maupun kawasan dalam bentuk area memanjang jalur di mana dalam penggunaannya lebih bersifat terbuka yang pada dasarnya tanpa bangunan. Ruang terbuka hijau kawasan perkotaan dapat dikatakan sebagai bagian dari ruang terbuka dalam kawasan perkotaan yang terdiri dari berbagai tumbuhan dan tanaman yang mempunyai manfaat mendukung eksistensi ekologi, sosial, budaya, ekonomi serta estetika lingkungan.

Adapun provinsi, wilayah kabupaten, dan wilayah kota, yang setiap wilayah tersebut merupakan subsistem ruang menurut batasan administratif. Maksudnya, pembedaan atas wilayah hanya pada kegiatan administrasi belaka. Di dalam subsistem tersebut terdapat sumber daya manusia dengan berbagai macam kegiatan pemanfaatan sumber daya alam dan sumber daya buatan. Sumber daya buatan ini diproduksi oleh manusia itu sendiri sebagai out put kreatifitasnya dalam memenuhi kebutuhannya.

Perbedaan administrative dan diversifikasi hasil kretifitas manusia juga berdampak pada pemanfaatan ruang yang berbeda-beda, yang apabila tidak ditata dengan baik dapat mendorong ke arah adanya ketidakseimbangan pembangunan antarwilayah serta ketidaksinambungan pemanfaatan ruang. Apalagi, berkaitan dengan penataan ruang wilayah kota.

Dalam regulasi mengenai tata ruang sebenarnya terdapat cara atau pendekatan penataan ruang. Pertama, dengan pendekatan kegiatan utama kawasan. Pendekatan ini terdiri atas penataan ruang kawasan perkotaan dan penataan ruang kawasan perdesaan. penataan ruang kawasan perdesaan diselenggarakan pada kawasan perdesaan yang merupakan bagian wilayah 
kabupaten atau pada kawasan yang secara fungsional berciri perdesaan yang mencakup 2 (dua) atau lebih wilayah kabupaten pada 1 (satu) atau lebih wilayah provinsi. Kawasan perdesaan yang merupakan bagian wilayah kabupaten dapat berupa kawasan agropolitan.

Kawasan perkotaan, menurut besarannya, dapat berbentuk kawasan perkotaan kecil, kawasan perkotaan sedang, kawasan perkotaan besar, kawasan metropolitan, dan kawasan megapolitan. Didalam penataan ruang kawasan metropolitan dan kawasan megapolitan dimaksud, khususnya kawasan metropolitan merupakan kawasan perkotaan inti dengan kawasan perkotaan di sekitarnya yang saling memiliki keterkaitan fungsional dan dihubungkan dengan jaringan prasarana wilayah yang terintegrasi. Hal ini merupakan pedoman untuk keterpaduan perencanaan tata ruang wilayah administrasi di dalam kawasan, dan merupakan alat untuk mengkoordinasikan pelaksanaan pembangunan lintas wilayah administratif yang bersangkutan.

Kawasan perkotaan dapat difahami sebagai kawasan yang mempunyai kegiatan utama bukan pertanian dengan susunan fungsi wilayah sebagai tempat permukiman, pemusatan dan distribusi pelayanan jasa pemerintahan, pelayanan sosial dan kegiatan ekonomi. Hal ini dapat kita lihat dalam kondisi real sekitar kita. Sebagai contoh di setiap kabupaten dalam suatu konsep penataan ruang berada di tengah-tengah kota dengan dikelilingi kantor Kabupaten sebagai pusat pemerintahan daerah, kemudian masjid agung sebagai pusat kegiatan religi, dan biasanya juga ada lembaga pemasyarakatan disana.

Penataan ruang terbuka hijau kawasan perkotaan di lakukan sebagai suatu proses perencanaan, pemanfaatan dan pengendalian kawasan hijau itu sendiri yang terdiri dari vegetasi yaitu, keseluruhan tumbuhan dan tanaman yang menutupi permukaan tanah. Selain itu juga ada yang disebut tanaman khas daerah. Tanaman khas daerah ini adalah jenis tumbuhan atau tanaman yang khas tumbuh dan menjadi identitas daerah sebagai ciri pembeda dari daerah yang lain.

Ruang terbuka hijau dalam kawasan perkotaan tidak lebih merupakan suatu struktur ruang kota yang merupakan susunan pusat-pusat permukiman sistem jaringan prasarana dan sarana di kota yang berfungsi sebagai pendukung kegiatan sosial ekonomi masyarakat yang secara hirarkis memiliki hubungan fungsional dalam masyarakat. Sehingga tujuan penataan ruang terbuka hijau kawasan perkotaan yang pertama, untuk menjaga keserasian dan keseimbangan ekosistem lingkungan perkotaan yang dari waktu ke waktu semakin dipertanyakan eksistensi keindahaanya. Kedua, mewujudkan kesimbangan antara lingkungan alam dan lingkungan buatan di perkotaan dan meningkatkan kualitas lingkungan perkotaan yang sehat, indah, bersih dan nyaman.

Dari beberapa poin mengenai tujuan tersebut juga dapat di kemukakan mengenai fungsi tata ruang hijau diperkotaan dapat sebagai pengamanan keberadaan kawasan lindung di daerah perkotaan, pengendali pencemaran, kerusakan tanah, air dan udara kemudian tempat perlindungan plasma nuftah, 
keanekaragaman hayati; pengendali tata air serta sarana estetika kota. Dengan begitu tata hijau kota memberikan kontribusi positif terkait dengan sarana untuk mencerminkan identitas daerah, sarana penelitian, pendidikan dan penyuluhan. Selain itu dapat juga sebagai sarana rekreasi aktif maupun pasif serta interkasi sosial. Kemudian bisa juga meningkatkan nilai ekonomi lahan perkotaan.

Dengan ciri khas perkotaan dengan lahan hijaunya mampu menumbuhkan rasa bangga dan meningkatkan prestise daerah, sarana aktivitas sosial bagi anakanak, remaja, dewasa dan manula dan yang lebih penting lagi dapat meningkatkan cadangan oksigen di perkotaan. Hal inilah sebenarnya yang menjadi sisi positif adanya tata ruang terbuka hijau di perkotaan.

Pembentukan tata ruang terbuka hijau harus disesuaikan dengan bentang alam yang didasarkan pada aspek biogeografis dan struktur ruang kota serta estetika, sehingga dapat mencerminkan karakter alam dan budaya setempat yang bernilai ekologis, historik, panorama yang khas dengan tingkat penerapan teknologi.

Didalam lingkungan perkotaan terdapat berbagai jenis ruang terbuka hijau menurut hukum positif yaitu :

a. taman kota; 
b. taman wisata alam;

c. taman rekreasi;

d. taman lingkungan perumahan dan permukiman;

e. taman lingkungan perkantoran dan gedung komersial;

f. taman hutan raya;

g. hutan kota;

h. hutan lindung;

i. bentang alam seperti gunung, bukit, lereng dan lembah;

j. cagar alam;

k. kebun raya;

1. kebun binatang;

m. pemakaman umum;

n. lapangan olah raga;

o. lapangan upacara;

p. parkir terbuka;

q. lahan pertanian perkotaan;

r. jalur dibawah tegangan tinggi (SUTT dan SUTET);

s. sempadan sungai, pantai, bangunan, situ dan rawa;

t. jalur pengaman jalan, median jalan, rel kereta api, pipa gas dan pedestrian;

u. kawasan dan jalur hijau;

v. daerah penyangga (buffer zone) lapangan udara; dan

w. taman atap (roof garden).

2. UPAYA - UPAYA MEWUJUDKAN TATA RUANG TERBUKA HIJAU MENUJU LINGKUNGAN SEHAT DAN ASRI MENURUT HUKUM PENATAAN RUANG

Ruang wilayah negara kesatuan Republik Indonesia dengan letak dan kedudukan yang strategis sebagai negara kepulauan merupakan sumber daya 
alam yang perlu dikelola secara terkoordinasi dan terpadu. Penggunaan sumber daya alam harus dilakukan secara terencana, rasional, optimal, bertanggung jawab, dan sesuai dengan kemampuan daya dukungnya, dengan mengutamakan sebesar-besar kemakmuran rakyat. Lebih dari itu perhatian kelestarian fungsi dan keseimbangan lingkungan hidup serta keanekaragaman hayati guna mewujudkan pembangunan yang berkelanjutan harus diutamakan. Selain itu juga sumber daya manusia dan sumber daya buatan dalam pola pembangunan yang berkelanjutan dengan mengedepankan wawasan lingkungan berlandaskan Wawasan Nusantara dan Ketahanan Nasional.

Rencana tata ruang yang memadukan dan menyerasikan tata guna tanah, air, dan sumberdaya alam lainnya dalam satu kesatuan tata lingkungan yang harmonis dan dinamis serta ditunjang oleh pengelolaan perkembangan kependudukan yang serasi disusun melalui pendekatan wilayah dengan memperhatikan sifat lingkungan alam dan lingkungan social baik perkotaan maupun dipedesaan.

Perkembangan dan pertumbuhan kota/perkotaan yang disertai dengan alih fungsi lahan yang pesat seperti pembangunan industri, kawasan rungkut, malmal dan berbagai macam pabrik yang kian menjamur di perkotaan telah menimbulkan dampak negative yaitu timbulnya kerusakan lingkungan yang dapat menurunkan daya dukung lahan dalam menopang kehidupan masyarakat di kawasan perkotaan, sehingga perlu dilakukan upaya untuk menjaga dan meningkatkan kualitas lingkungan melalui penyediaan ruang terbuka hijau yang memadai. Untuk itu mewujudkan tata ruang terbuka hijau menuju lingkungan sehat dan asri dilakukan penataan atas kawasan hijau daerah perkotaan tersebut dengan tahapan-tahapan sebagai berikut :

\section{A. Perencanaan}

Dalam tahap ini merupakan bagian yang tidak terpisahkan dari rencana tata ruang wilayah provinsi dan kabupaten/kota. Sehingga setiap perencanaan harus dituangkan dalam rencana detail tata ruang kawasan perkotaan dengan skala peta sekurang-kurangnya 1:5000 dan dengan luas ideal kawasan hijau minimal 20\% dari luas kawasan perkotaan. Nominal tersebut meliputi wilayah publik dan privat dengan pembagian untuk publik penyediaannya menjadi tanggungjawab pemerintah dan dilakukan secara bertahap sesuai dengan kemampuan masingmasing daerah. Sedangkan untuk wilayah privat dimaksud dalam penyediaannya menjadi tanggung jawab pihak ataupun lembaga swasta, perseorangan dan masyarakat yang dikendalikan melalui izin pemanfaatan ruang oleh Pemerintah. Perencanaan ini memuat jenis, lokasi, luas, target pencapaian luas, kebutuhan biaya, target waktu pelaksanaan, dan disain teknis.

B. Pemanfaatan

Tahapan rencana tata ruang wilayah ini meliputi pembangunan baru, pemeliharaan, dan pengamanan ruang terbuka hijau. Pemanfaatan publik dikelola oleh Pemerintah Daerah dengan melibatkan para pelaku pembangunan. Lingkup 
publik tidak dapat dialihfungsikan meskipun dapat dikerjasamakan dengan pihak ketiga ataupun antar pemerintah daerah. Begitu juga pemanfaatan privat dapat dikelola oleh perseorangan atau lembaga sesuai dengan peraturan perundanganundangan. Pemanfaatan kawasan hijau diperkaya dengan memasukkan berbagai kearifan lokal dalam penataan ruang dan konstruksi bangunan taman yang mencerminkan budaya setempat. Pemanfaatan sebagaimana dimaksud dapat pula dikembangkan dengan mengisi berbagai macam vegetasi yang disesuaikan dengan ekosistem dan tanaman khas daerah. Vegetasi disesuaikan dengan bentuk dan sifat serta peruntukannya, yaitu:

a. Botanis, merupakan campuran jenis pohon ukuran kecil, ukuran sedang, ukuran besar, perdu setengah pohon, perdu, semak dan tanaman penutup tanah/permukaan;

b. Arsitektural, merupakan heterogenitas bentuk tajuk membulat, menyebar, segitiga, bentuk kolom, bentuk tiang, memayung dan menggeliat, serta mempunyai nilai eksotik dari sudut warna bunga, warna daun, buah, tekstur batang, struktur percabangan; dan

c. Tanaman yang dikembangkan tidak membahayakan manusia dan memperhatikan nilai estetika.

C. Pengendalian

Tahapan rencana tata ruang wilayah ini dilakukan melalui perizinan, pemantauan, pelaporan dan penertiban. Pengendalian berarti memposisikan kondisi atau suatu hal diluar, harus sesuai dengan keinginan kita. Untuk itu halhal yang diperhatikan yaitu :

a. target pencapaian luas minimal;

b. fungsi dan manfaat;

c. luas dan lokasi; dan

d. kesesuaian spesifikasi konstruksi dengan desain teknis.

\section{PENUTUP}

\section{Kesimpulan}

Adapun kesimpulan dari penulisan penelitian ini adalah sebagai berikut:

1. Konsep tata ruang terbuka hijau perkotaan perspektif hukum penataan ruang merupakan bagian dari ruang terbuka suatu kawasan perkotaan yang diisi oleh tumbuhan dan tanaman guna mendukung manfaat ekologi, sosial, budaya, ekonomi dan estetika;

2. Upaya - upaya mewujudkan tata ruang terbuka hijau menuju lingkungan sehat dan asri menurut hukum penataan ruang meliputi perencanaan, pemanfaatan serta pengendalian.

\section{Saran}

Mengenai saran atau rekomendasi yang hendak Penulis tawarkan ialah : 
1. Dalam mewujudkan tata ruang kota yang asri pemerintah harus memperhatikan serta berupaya untuk menjaga dan meningkatkan kualitas lingkungan melalui penyediaan ruang terbuka hijau yang memadai;

2. Upaya - upaya mewujudkan tata ruang terbuka hijau menuju lingkungan sehat dan asri harus melibatkan semua lapisan masyarakat, tokoh agama, tokoh masyarakat guna menyatukan langkah dan persepsi. 


\section{DAFTAR PUSTAKA}

\section{Buku :}

Johny Ibrahim, Teori dan Metodologi Penelitian Hukum Normatif, Bayu Media Publishing, Malang, 2006.

Peter Mahmud Marzuki, Penelitian Hukum, Prenada Media, Surabaya, 2005.

Soetandyo Wignyosoebroto, Hukum, Paradigma, Metode dan Dinamika Masalahnya, Elsam dan Huma, Jakarta, 2002.

\section{Perundang-undangan :}

Undang-Undang Dasar 1945

Undang-Undang Republik Indonesia Nomor 26 Tahun 2007 Tentang Penataan Ruang

Peraturan Pemerintah Nomor 47 Tahun 1997 tentang Rencana Tata Ruang Wilayah Nasional

Peraturan Menteri Dalam Negeri Nomor 1 Tahun 2007 tentang Penataan Ruang Terbuka Hijau Kawasan Perkotaan

\section{Internet :}

Siaran Pers: Jumat, 17 Desember 2004 dalam situs www.walhi.or.id 